\title{
THE TRANSLATION OF ENGLISH TENSES AND ASPECTS IN NARRATIVE MODE INTO VIETNAMESE
}

\author{
Nguyen Dinh Sinh* \\ Faculty of Foreign Languages, Hung Yen University of Technology and Education \\ Nhan Hoa, My Hao, Hung Yen \\ Received 13 March 2020 \\ Revised 21 May 2020; Accepted 24 November 2020
}

\begin{abstract}
Confusion due to ambiguity in tenses and aspects while translating from English into Vietnamese is still a common problem to translators. There are several causes to this problem, but the main cause is the difference in viewing tense and aspect notions in the two languages by researchers or scholars. The existence of tense and aspect identities in English clauses or sentences is a matter of fact whereas in Vietnamese they are the topic of controversy among linguists and educators. This article investigates some of the linguistic means that were employed to translate English tenses and aspects in narrative mode into Vietnamese by three well-known translators, namely Mặc Đỗ, Hoàng Cường and Trịnh Lữ. The results of the study prove the fact that though tenses and aspects are not always recognized in the Vietnamese language, they can be translated from the English language via the use of temporal adverbials, aspectual markers or situation types of Vietnamese verbs.
\end{abstract}

Keywords: aspects, aspectual markers, narrative mode, situation types of verbs, temporal adverbials, tenses, translation.

\section{Introduction}

Normally, in any English expressions in the form of sentences, the use of correct tenses and aspects is the matter of fact that every English user should be aware of. This implies that tenses and aspects are compulsory in all English sentences, whereas the notions of tenses and aspects in Vietnamese are so vague that they are even suspected of their existence as a grammatical identity. The vagueness can be seen from the controversial views of linguists. Some state that Vietnamese has tenses and aspects (Nguyen, 1963; Diep, 1992; Nguyen, 1980), while the others affirm that Vietnamese has no tense but aspect categories (Hoang, 1962; Nguyen, 1977; Xuan, 1984). Hence, in translation, finding equivalence with regard to tenses and aspects between the two languages like English and Vietnamese,

*Tel.: 0943403168, Email: Mrsinh09@gmail.com. however, has not always been a simple task. This kind of equivalence belongs to grammar level as Bell (1993, p. 6) states that "Texts in different languages can be equivalent in different degrees (fully or partially equivalent), in respect of different levels of presentation (equivalent in respect of context, of semantics, of grammar, of lexis, etc.)".

With the main aim to find out what equivalent means were used to translate English tenses and aspects into Vietnamese, the researcher carried out the current study. To achieve that aim, selected data of 149 sentences in the English source language (SL) were taken from the novel "The Great Gatsby" (hereafter referred to as TG) by Francis Scott Fitzgerald. Basically, sentences in a novel may fall into two modes, namely deictic mode and narrative one; however, due to the scope of the present study, the former mode was not considered, the later mode was examined 
instead. Of these data, 58 sentences are in simple present tense, 46 sentences belong to simple past tense and 45 sentences are in past progressive tense. The data in Vietnamese were equivalent translated sentences taken from three translated novels. Furthermore, the researcher employed the traditional theories stating that English has a system of 12 tenses and aspects, the combination of using adverbials in expressing time in the Vietnamese language, aspectual markers and theories of situation types of verbs and equivalence in translation. The study is expected to obtain useful results serving as a good reference for those who are interested in translation.

\section{Literature review}

\subsection{The notions of tense and aspect}

Vietnamese learners when first studying English may confuse between tense and aspect categories. These two categories seem simple, but differentiating them requires extensive understanding, given their various definitions. Tense, for example, has been variably interpreted under dissimilar linguistic perspectives. Jespersen (1931) regards tenses as the relations of time through the indications of verb forms. Sharing the view of tenses through forms of verbs, Finch (2005) believes tenses make changes to the form of a verb. Likewise, Richards and Schmidt (2002, p. 545) remark the connection of the verb form and time as affirming tense as "the relationship between the form of the verb and the time of the action or state it describes". Apart from the above definitions, tense is deemed to bear the relation with grammar as Comrie (1985) believes that tense is the location in time and it is grammaticalized. Similarly, considering tense as a category of grammar, Trask (2008) says that tense is "the grammatical category which relates to time". Specially, in judging the deictic state of the action, i.e., the time of the action with other related time, Salaberry and Shirai (2002) hypothesize tense to be a deictic category situating in time concerning some other time, normally the speech moment.

The term "aspect" originated from Russian word "vid" to become popular in English in the mid-18th century. In fact, aspect category has been studied since ancient times. Since then, quite many definitions of aspect have been proposed. Compared to the definitions of tense, aspect is observed differently. According to Comrie (1976, p. 3), aspect refers to the internal time of a situation, while tense cares about how a situation is related to a time-point. His popular aspect definition is "aspects are different ways of viewing the internal temporal constituency of a situation". Likewise, in showing the concern about the time point of the action, Jarvie (1993) stresses the starting point of the action then comes to view it as aspect. Besides, under grammatical view, Greenbaum and Quirk (2003, p. 51) state "aspect is a grammatical category that reflects the way in which the action of a verb is viewed with respect to time". Then, taking the metaphorical comparison of aspect with a camera, Smith (1997) views aspect under the angle like the lens of a camera as it helps the receiver see objects that are situations. In general, both tense and aspect are concerned about time of the action, the former is pertained to other time points while the later deals with the time within the situation itself. As a result, the forms of the verbs vary in pursuance to different tenses and aspects they bear. Nonetheless, meanings of the verbs are justified not only by the forms of the verbs but also by situation types of verbs. Thus, Vendler (as cited in Geeraerts \& Cuyckens, 2007) divided English verbs into four types. They are states, activities, accomplishments 
and achievements. According to Vendler (1967), state verbs are verb phrases that express stative, durative and atelic situations, such as sit, hold, like, stand, think, know, live, love. Activities are those verbs expressing dynamic and durative situations such as look for, run, talk, speak, walk, push, read, write, eat, beat, dance. Accomplishments are verb phrases stating dynamic and telic situations such as read a book, eat a bowl of rice, write a letter, wash the face, go to school, stand up. Achievements consist of verb phrases that indicate punctual or instantaneous telic situations, such as die, explode, find, break, nod the head, blow out.

Besides, along with the different views towards the notions of tense and aspect the classification of them does not seem to be less various. In categorizing types of tense and aspect, linguists perceive different opinions towards the number of tenses and aspects in English. Even, one linguist may have dissimilar viewpoints towards tenses and aspects himself. That is the case of Davidsen (1990) who affirms that he gets influence from Bach (1947) and Comrie (1985), by whom tense is described as "grammaticalised location in time". As a result, he states "in my book from 1990 I operate with eight tenses in English: present, present perfect, past, past perfect, future, future perfect, future past and future perfect of the past" (Davidsen, 1990, p. 148). Then after analyzing other linguists' views with respect to tense and aspect, he concludes that "English has two tenses (present and past) and two aspectual distinctions (perfect: nonperfect and progressive: non-progressive)" (Davidsen, 1990, p. 154). Viewing tenses under morphological angle, according to Downing and Locke (2006), "English has just two tenses: the Present and the Past, as in goes/went, respectively". Besides, Declerck et al. (2006) state that English traditionally has seven tenses namely present tense, past tense or 'preterite', future tense, present perfect, past perfect or 'pluperfect', conditional tense and conditional perfect.

While mentioning verb tenses, Alexander (1998) divides English tenses into the simple present, present progressive tenses, the simple past tense, the past progressive tenses, the simple present perfect, present perfect progressive, the simple past perfect, past perfect progressive tenses, the simple future tense, the future progressive, the future perfect and going to and other ways of expressing the future. This division of tenses and aspects by Alexander (1998) seems to conform with the reseacher's expectation in later analyses, thus it will be taken as a theoretical base for the current study.

In general, Vietnamese scholars of other fields rather than languages are not aware of the notions of tenses and aspects. Even among linguistic researchers, there exist different trends in arguing if tenses and aspects are present in the Vietnamese grammar. The arguments not only captivate Vietnamese linguistic researchers but also linguistic researchers abroad. The first trend claims that Vietnamese has tenses as expressed in đã, đang, sẽ in Vietnamese which are the indicators of past tense, present tense and future tense respectively (Nguyen, 2009; Bui, 1952; Nguyen, 1988; Diep, 1992; Nguyen \& Nguyen, 1998). The second trend states that Vietnamese has no tenses (Tran, Bui \& Pham, 1940; Emeneau, 1951; Hoang, 1962; Nguyen, 1996). Besides, Cao (1998) claims that Vietnamese has no category to show tense though it has the category of aspect.

Practically, the expression of the time of an action in Vietnamese, according to Tran (1940), can be relied on various adverbials like hôm qua, bũa ấy, tháng trước, ngày xua 
and so forth to show the action happened in the past. Such adverbs as bây giờ, lúc này, nay, hôm nay, tuần này and so on can be used to indicate action happening at present. To express the action happening in the future, Vietnamese people may use adverbs like chốc nũa, lát nũa, mai này, về sau, ngày mai, tuần tới, hai tháng nũa and so on. Besides, in telling if the action has finished or not or it is still in progress, Vietnamese has different adverbs like đã, rồi, còn, vẫn, đang and sẽ.

Furthermore, Dinh (2012) states that such expletives like đã, đang, sẽ, tùng còn, vì̀a, mó $i$, etc. have been considered as indicators referring to past tense, present tense and future tense for a long time by Vietnamese linguists. $\mathrm{He}$ affirms that the tense-aspect relationship in the Vietnamese language is integrated as a grammar-state relationship. Such words as $đ \tilde{a}$, đang, sẽ on one hand are to express the state meaning of the whole sentence, and on the other hand are to maintain the tight relationship between tense and aspect meaning of the predicate. In the below examples, he points out those words indicate the relationship but not kind of tense and aspect meaning. Firstly, đã in the subsequent sentence is not used as an indicator for past tense:

(1) Đã viết tiểu thuyết lại còn làm thơ.

Not only writing novels but also composing poems.

Or dang is not the expression of present tense in:

(2) Đang giữa trưa hè, không một ngọn gió.

It was in a summer noon, there was not any wind.

And $s \tilde{e}$ does not refer to future tense in:

(3) Cái áo này chắc chắn sẽ không dưới ba trăm ngàn.
This shirt is surely not under 300,000 VND.

As can be seen from the above stated parts and examples, the equivalents of tense and aspect in English can be found in the Vietnamese language under the forms of adverbials, aspectual markers or expletives, though they are not always completely satisfied and correct choices. However, this issue in practice may become even more difficult as how a translator can deal with sentences in English that have no adverbs of time. Then, the issue is supposed to be solved counting on the use of situation types of verbs as Nguyen (2006) provides a more detailed description of Vietnamese types of situation based on the descriptions provided by Vendler (1967) and Smith (1997). He differentiates five types of situations: activities, accomplishments, achievements, states and semelfactives. This classification is the same as Vendler and especially as Smith's classification. Thus, it is hypothesized that the three Vietnamese translators of the novel "the Great Gatsby" would have been aware of and come to employ a number of different adverbs and situation types of verbs in Vietnamese to translate tenses and aspects into Vietnamese.

Translation is normally, in reality, the process of finding an appropriate translation approach to identify equivalent items. Therefore, the following part will be discussions of translation approaches and equivalence.

\subsection{Notions of translation and translation equivalence}

\section{Notions of translation}

Translation practice dates back to thousands of years. Translation theories, however, have just been developed in recent decades. Noteworthy, since the emergence of theories in translation, there have been 
numerous viewpoints towards the notions of translation. Jakobson (1959) was regarded as one of the first researchers of the $20^{\text {th }}$ century to propose a concept of translation. Translation, according to Jakobson (1959), is the substitution of the whole messages rather than the separate code-units only. Nida states, "definitions of ... translating are almost as numerous and varied as the persons who have undertaken to discuss the subject" (Nida, 1964, p. 161). While observing the translation process, Catford (1965) simply believes that translation is the alternative of meaning of a language with another one. He states "the replacement of textual material in one language (SL) by equivalent textual material in another language (TL)" (Catford, 1965, p. 20). In defining the notion of translation, Newmark (1988) is concerned more about the author of the text as he thinks that the translator should understand the intention of the author in transferring the meaning of the text into another language.

\section{Translation equivalence}

Translation can be regarded as a process of finding equivalents from the target language for the source language. Thus, equivalence has an adjacent correlation with semantic entity. Jakobson (1959) believes that "equivalence in meaning" emphasizes more on "differences in the structure and terminology of languages" than on the non-equivalent items between the two languages.

When discussing equivalence in translation Venuti (2000, p. 5) believes "equivalence has been understood as 'accuracy', 'adequacy', 'correctness', 'correspondence', 'fidelity', or 'identity'; it is a variable notion about how the translation is connected to the foreign text". Munday (2001) takes equivalence in translation as the central focus in his studies. Kenny (1998) states that translation equivalence a core notion; therefore, it can be also a topic of controversy.

The theories about translation equivalence proposed by Nida (1964) pointed out two equivalence types, namely dynamic equivalence and formal equivalence. Dynamic equivalence puts more emphasis on context and the adaptation of sense whereas formal equivalence is aware of the method of translating word for word and the faithfulness towards the content. Besides, Baker (1992) seems to provide the most detailed condition index for the definition of equivalence concept. Equivalence concept is then viewed at various levels of translation equivalence namely equivalence of word, equivalence of grammar, equivalence of text and equivalence of pragmatics. In the grammatical level, number, voice, tense and aspect, person and gender receive more attention. As the present study is aimed at finding out how to translate temporal items and aspectual items, thus the study is targeted at identifying equivalence of grammatical expressions.

\section{Methodology}

Due to the small scope of the study, the present study merely explored the means that the translators had employed to translate some selected tense and aspect sentences from English in a narrative manner. The sentences selected as data for analysis are expressed in the simple present tense, the past progressive tense and the simple past tense in the Vietnamese version via the use of adverbs of time, especially via the use of situation types of verbs. The data of 149 sentences were taken from "The Great Gatsby" novel written in 1925 by American author Francis Scott Fitzgerald as the source language (SL). Bearing in mind that there would be no differences in the use of a particular English tense or aspect in different cases, hence these sentence data 
were only randomly selected from the whole nine chapters of the novel. The corresponding Vietnamese translated sentences are from “Anh chàng hào hoa" by Mặc Đỗ (hereafter called T1), "Gatsby vĩ đại” by Hoàng Cường (hereafter called T2) and "Đại gia Gatsby" by Trịnh Lũ̃ (hereafter called T3). Notably, within the extent of this study, only narrative sentences of present simple tense, past progressive tense and simple past tense from the English novel (TG) are taken into account. The study aimed at investigating possible linguistic means applied by T1, T2, and T3 to translating tenses and aspects from English into Vietnamese. Therefore, the following questions are proposed to be answered so as to obtain the objectives of the study:

1. How can English tenses be translated into Vietnamese?

2. How can English aspects be translated into Vietnamese?

Basing on the afore-mentioned literature review, the researcher created himself a theoretical framework in the form of a table to analyze equivalents and nonequivalents as regards tense and aspect of the two languages English and Vietnamese. The three selected tenses were evaluated concerning the means of translations used by the three translators T1, T2 and T3. The used means were temporal adverbials referring to present, past or future. They can also be aspectual markers like progressive or perfective. Unless those two sorts of means were used, the means could belong to situation types of verbs such as state, activity, accomplishment or achievement. The proposed table below serves as a framework to collect data for the study.

Table 1: Framework for translating of tense and aspect from English into Vietnamese

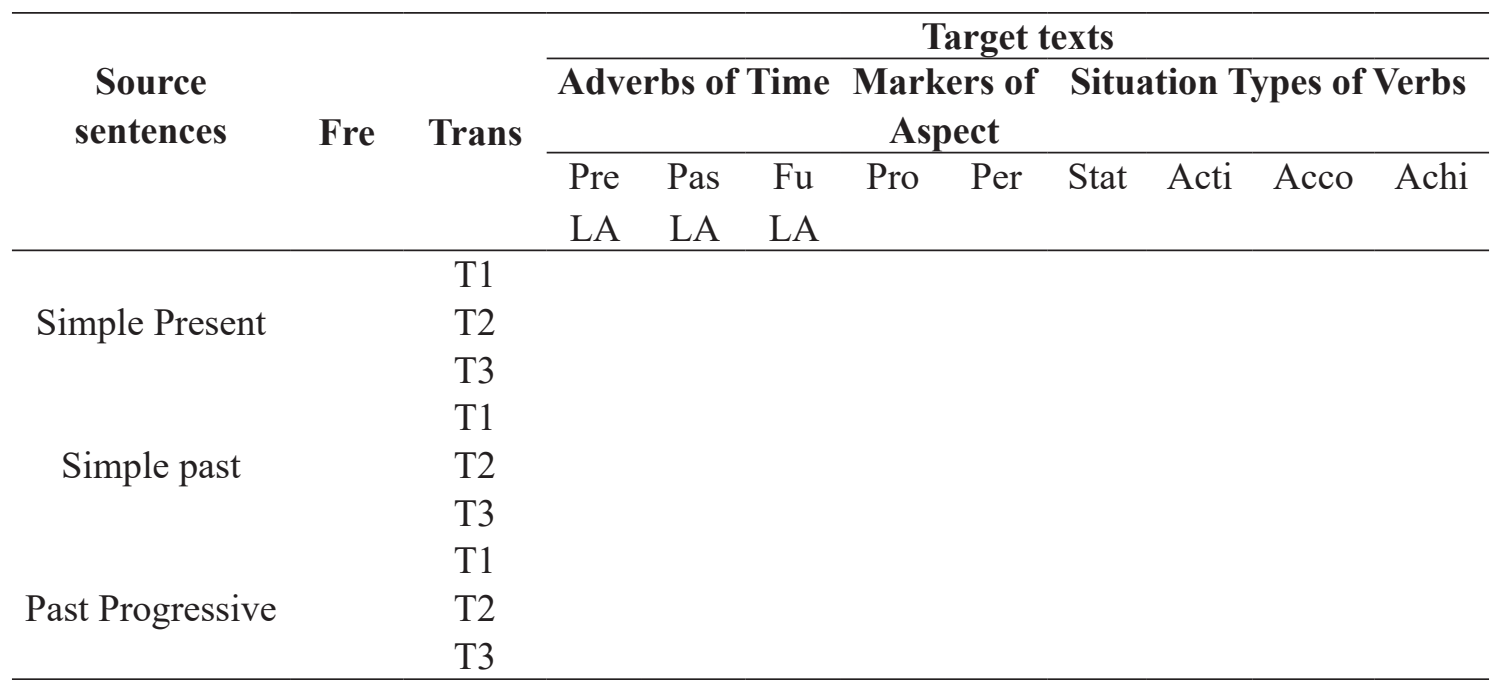

Legend: Fre: frequency; Acti: activity; Acco: accomplishment; Achi: achievement; Stat: state; Trans: Translators; Pre: Present; Fu: Future; Pro: progressive; Per: perfect; LA: Locating adverbials

The author employed descriptive, comparative and contrastive methods to form a theoretical framework for the present study. Moreover these methods were also employed to analyze the data, These methods helped to analyze and synthesize the similarities and differences in expressing tenses and aspects between English and Vietnamese.

\section{Results and discussion}

The aims of the current study are to find out the answers to the questions of how English tenses 
and aspects can be translated into Vietnamese. The results of the study show that tenses and aspects present in the sentence data of the present simple tense, the past tense and the past progressive tense were translated via different means by the three Vietnamese translators. These means of translation would serve as answers to the questions of the present study.

Table 2: Translation of English tenses and aspects into Vietnamese

\begin{tabular}{|c|c|c|c|c|c|c|c|c|c|c|c|}
\hline \multirow{4}{*}{$\begin{array}{c}\text { Source } \\
\text { sentences }\end{array}$} & \multirow{4}{*}{ Fre } & \multirow{4}{*}{ Trans } & \multicolumn{9}{|c|}{ Target texts } \\
\hline & & & \multicolumn{3}{|c|}{$\begin{array}{c}\text { Adverbs of } \\
\text { Time }\end{array}$} & \multicolumn{2}{|c|}{$\begin{array}{l}\text { Markers } \\
\text { of Aspect }\end{array}$} & \multicolumn{4}{|c|}{ Situation Types of Verb } \\
\hline & & & Pre & Pas & $\mathrm{Fu}$ & Pro & Per & Stat & Acti & Acco & Achi \\
\hline & & & LA & LA & LA & & & & & & \\
\hline \multirow{4}{*}{ Simple Present } & \multirow{3}{*}{58} & $\mathrm{~T} 1$ & 3 & & & 1 & 2 & 35 & 8 & 3 & 6 \\
\hline & & $\mathrm{T} 2$ & 4 & & & & 1 & 42 & 3 & 3 & 5 \\
\hline & & $\mathrm{T} 3$ & 5 & & & 3 & 4 & 37 & 5 & 1 & 3 \\
\hline & \multirow{3}{*}{46} & $\mathrm{~T} 1$ & & & & & 3 & 21 & 11 & 7 & 4 \\
\hline \multirow[t]{3}{*}{ Simple past } & & $\mathrm{T} 2$ & 1 & 4 & & & 2 & 24 & 10 & 3 & 2 \\
\hline & & $\mathrm{T} 3$ & & & & 2 & 3 & 20 & 9 & 7 & 5 \\
\hline & \multirow{3}{*}{45} & $\mathrm{~T} 1$ & & & & 12 & 1 & 22 & 2 & 6 & 2 \\
\hline \multirow[t]{2}{*}{ Past Progressive } & & $\mathrm{T} 2$ & 3 & & & 8 & 5 & 16 & 2 & 8 & 3 \\
\hline & & $\mathrm{T} 3$ & 1 & & 1 & 26 & 1 & 2 & 7 & 6 & 1 \\
\hline
\end{tabular}

Legend: Fre: frequency; Acti: activity; Acco: accomplishment; Achi: achievement; Stat: state; Trans:

Translators; Pre: Present; Fu: Future; Pro: progressive; Per: perfect; LA: Locating adverbials

\subsection{The result analysis}

\subsubsection{The translation of tenses and aspects from English into Vietnamese translation by $T 1$.}

A number of 149 sentences in (TG) were taken as corpus. The selected tenses are simple present tense, past progressive tense and simple past tense. The number of sentences of simple past tense are 58, thus accounting for 39 percent of the total sentences and becomes the biggest. Coming next are the sentences of simple past tense rated the second as they constitute 31 percent i.e. 46 sentences while 45 sentences of the past progressive tense are smallest as they account for 30 percent. The contrast of tense and aspect translation will be clearly seen in the following illustrations:

Table 3: Means applied to translating tenses and aspects by $\mathrm{T} 1$

\begin{tabular}{|c|c|c|c|}
\hline \multicolumn{4}{|c|}{ Total sentences 149} \\
\hline \multicolumn{2}{|c|}{ Direct adverbs $22(14.7 \%)$} & \multicolumn{2}{|c|}{ Situation types of verbs $127(85.3 \%)$} \\
\hline PerAM & $6(27.3 \%)$ & Stat & $78(61.4 \%)$ \\
\hline AoT & $3(13.6 \%)$ & Acti & $21(16.5 \%)$ \\
\hline \multirow[t]{2}{*}{ ProAM } & $13(59.1 \%)$ & Acco & $16(12.6 \%)$ \\
\hline & & Achi & $12(9.5 \%)$ \\
\hline
\end{tabular}

Legend: Acti: activity; Acco: accomplishment; Achi: achievement; Stat: state; PerAM: Perfect Aspectual Markers; AoT: Adverbs of Time; ProAM: Progressive Aspectual Markers

Only $22(14.7 \%)$ out of the 149 sentences were found to be explicitly transferred into Vietnamese via a direct adverb indicating tense or aspect. Progressive aspectual markers were found the most frequently used in 13 sentences $(59.1 \%)$. Followed by perfect 
aspectual markers indicating tense detected in 6 sentences $(27.3 \%)$. Then adverbs of time were utilized the least frequent, noticed in 3 sentences (13.6\%). The rest of 127 sentences $(85.3 \%)$ were found to be conveyed by means of the situation types of verbs. Among them state verbs were identified to be the most frequently used, observed in 78 sentences making up 61.4 percent. Then 21 sentences of activity verbs (16.5\%), followed by accomplishment verbs found in 16 sentences $(12.6 \%)$ are also located. The achievement verbs belonged to the least often used group, discovered in 12 sentences $(9.5 \%)$.

\subsubsection{The translation of tenses and aspects from}

English into Vietnamese translation by $T 2$.

Table 4: Means applied to translating tenses and aspects by T2

\section{Total sentences 149}

\begin{tabular}{cccc}
\multicolumn{2}{c}{ Direct adverbs 28 (18.8\%) } & \multicolumn{2}{c}{ Situation types of verbs $\mathbf{1 2 1}(\mathbf{8 1 . 2 \% )}$} \\
\hline PerAM & $8(28.6 \%)$ & Stat & $82(67.8 \%)$ \\
AoT & $12(42.8 \%)$ & Acti & $15(12.4 \%)$ \\
ProAM & $8(28.6 \%)$ & Acco & $14(11.6 \%)$ \\
& & Achi & $10(8.2 \%)$ \\
\hline
\end{tabular}

Legend: Acti: activity; Acco: accomplishment; Achi: achievement; Stat: state; PerAM: Perfect Aspectual Markers; AIT: Adverbs of time; ProAM: Progressive Aspectual Markers

Taking the same data of (SL) sentences to contrast with the equivalent translation by $\mathrm{T} 2$, however, the results are somehow different from the means of translation applied by T1. The difference can be reflected from the illustrations below:

The 28 (18.8\%) out of the 149 sentences in narrative manner, were recognized to be directly translated into Vietnamese via a direct adverb indicating tense or aspect. Different from the result by $\mathrm{T} 1$ as adverbs of time showing tense and aspect were the most frequently used by $\mathrm{T} 2$ found in 12 sentences (42.8\%). Surprisingly, perfect aspectual markers and progressive aspectual markers were equally employed in 8 sentences $(28.6 \%)$. The remainder of 121 sentences $(81.2 \%)$ was discovered to be translated via the use of the situation types of verbs. Interestingly, state verbs once more were found out to be the most regularly used, present in 82 sentences making up 67.8 percent. Following was activity verbs found in 15 sentences (12.4\%). Accomplishment verbs were found in 14 sentences $(11.6 \%)$ whereas the achievement verbs were the least frequently applied, seen in 10 sentences $(8.2 \%)$.

\subsubsection{The translation of tenses and aspects from English into Vietnamese translation by T3.}

Table 5: Means applied to translating tenses and aspects by T3

\begin{tabular}{crrr}
\hline \multicolumn{2}{c}{ Total sentences 149 } \\
\hline & \multicolumn{2}{c}{ Situation types of verbs } \\
$\mathbf{1 0 3}(\mathbf{6 9 . 1 \% )})$ \\
\hline PerAM & $8(\mathbf{3 0 . 9 \% )}$ & Stat & $59(57.3 \%)$ \\
AoT & $7(15.2 \%)$ & Acti & $21(20.4 \%)$ \\
ProAM & $31(67.4 \%)$ & Acco & $14(13.6 \%)$ \\
& & Achi & $9(8.7 \%)$ \\
\hline
\end{tabular}

Legend: Acti: activity; Acco: accomplishment; Achi: achievement; Stat: state; PerAM: Perfect Aspectual Markers; AIT: Adverbs of time; ProAM: Progressive Aspectual Markers 
Likewise, data of English sentences keep unchanged, however, the employment of tense and aspect equivalents by $\mathrm{T} 3$ are a bit different from the other two translators. The difference seems to be unavoidable yet if the difference would distort the plot of the novel or not, a detailed analysis would be able to make it clearer.

Table 4 above shows that $46(30.9 \%)$ out of the 149 sentences in narrative manner were directly translated into Vietnamese via a direct adverb indicating tense or aspect. Correspondingly, progressive aspectual markers were observed the most frequently used in 31 sentences (67.4\%). Then the frequency of perfect aspectual markers ranked the second as being noted in 8 sentences (17.4\%). Besides, adverbs of time indicating tense and aspect were observed to be used the least often, found in 7 sentences $(15.2 \%)$. The leftover of 103 sentences $(69.1 \%)$ was identified to be translated through the use of the situation types of verbs. Surprisingly, state verbs were repeatedly found out to be the most regularly used, exhibited in 59 sentences making up 57.3 percent. This was then followed by activity verbs found in 21 sentences (20.4\%). Besides, the achievement verbs were used the least often, found in 9 sentences $(8.7 \%)$ whereas accomplishment verbs were found in 14 sentences (13.6\%) which are in contrast to the analysis results of the afore translated versions.

\subsection{Discussion}

As can be seen from the above data analyses, English tenses and aspects were translated into Vietnamese via different means, such as direct adverbs and situation types of verbs. While different types of Vietnamese adverbs were utilized, various verbs of different situation types were the most frequently employed.
These types of adverbs and verbs were all mentioned in the literature review. Following are some detailed illustrations. Firstly, adverbs indicating a finished action in Vietnamese are so-called perfect aspectual markers like rồi, đã, etc. For example:

(4) I knew his whole family history before he left. (TG, p. 136)

T2: Trước khi hắn đi em đã biết hết lai lịch nhà hắn.

Looking at the Vietnamese translation of the above example, the adverb or aspectual marker "đã" successfully conveys the meaning of a completed action of the verb "knew". However, "đã " in the following example does not imply the finished action of the verb "give"

(5) Only Gatsby, the man who gives his name to this book, was exempt from my reaction (TG, p. 4)

T3: Chỉ có Gatsby, người mà tôi đã lấy tên đặt cho quyển sách này...

Or "rồ" in the following sentence does not mean the action of getting married is finished; instead, it is used for emphasizing.

(6)'When they do get married,' (TG, p. 37)

$\mathrm{T} 1$ : Khi lấy được nhau rồi.

But "rồ $i$ " in the translation below really does express a completed action of the verb "came"

(7) I enjoyed the counter-raid so thoroughly that I came back restless. (TG, p. 5)

T3: Tôi khoái cuộc phản công ấy đến nỗi đã về rồi mà vẫn bồn chồn không yên.

Secondly, adverbs of time like tuần truoóc, tháng trước, hôm qua, etc. were used. The use of adverbs of time is the same in English and Vietnamese and this was mentioned in the literature review. Illustration for this can be seen in the translation below. 
(8) but we met you here about a month ago. (TG, p. 47)

T1: Nhưng tháng trước chúng tôi đã gặp chị ở đây một lần.

Thirdly, adverbs indicating the action in progress like đang, sẽ etc. as an example:

(9) I had that familiar conviction that life was beginning over again ... (TG, p. 6)

T3: Tôi lại tin rằng cuộc sống đang khắp khởi sự lại từ đầu..

The use of adverb "đang" was used by the author to express action in progress but in this situation, the progress was in the past not at present.

Or "sẽ" was used to indicate the action in present perfect tense but not in the progressive aspect.

It is invariably saddening to look through new eyes at things upon which you have expended your own powers of adjustment. (TG, p. 112)

T1: Không tài tránh khỏi đau buồn khi ta nhìn bằng cặp mắt mới những thứ gì mà chính ta sẽ bỏ công sức điều chỉnh

Fourthly, situation types of verbs carrying tenses and aspects in English are translated into equivalent verbs in Vietnamese. An illustration is as follows:

(11) God, how I hated that town! (TG, p. 38)

T2: Trời ạ, tôi ghét thành phố ấy đến thế.

The verb "hate" is a state verb and it was discussed in the literature review, thus in the above-said example the verb "hated" was translated into "ghét"

Or sentences in which no adverbial is recognized and their verbs may fall into activity, accomplishment or achievement types according to Vendler (1967) theory of situation types of verbs as stated in the above section. Hence, the first example of this type is the use of an activity verb for tense and aspect translation.

(12) He walked around the room quickly, ringing bells. (TG, p. 109)

T1: Anh nhanh nhẹn đi lại trong phòng, rung chuông

Then coming next is the case of using accomplishment verb for translation.

He reads deep books with long words in them. (TG, p. 16)

T3: Anh ấy đọc những sách thâm thúy có những chữ rất dài.

Finally, an achievement verb in Vietnamese is used to convey the meaning of similar achievement verb type containing tense and aspect meaning in English.

Making a short deft movement Tom Buchanan broke her nose with his open hand. (TG, p. 41)

T2: Bằng 1 động tác gọn và chính xác, Tom Buchanan xòe tay đánh chảy máu mũi người tình của mình.

\section{Conclusion and implications}

With the aims set out to seek for methods or ways to translate English tenses and aspects into Vietnamese, the author applied descriptive, comparative and contrastive methods for his study to find out the results for the stated aims. The study found that with the use of the resources of adverbs indicating tenses and aspects and especially the use of situation types of verbs in Vietnamese, the three Vietnamese translators could render sentences as regards tenses and aspects from a richly tensed language like English into a non-tense language. It is noteworthy that in this research, only sentences of the three 
selected tenses are analyzed. Hence, based on the above result analysis it can be concluded that tense or aspect in English can be translated into Vietnamese by using different adverbs indicating temporal and aspectual elements. Specifically, a sentence in simple present tense in English can be translated into Vietnamese via the use of not only present adverbs indicating tense but also aspectual markers expressing the action in progress or in perfective state or even it can be translated by means of situation types of verbs. Another conclusion is for the sentences in simple past tense. These sentences can be conveyed into Vietnamese through the use of perfective aspectual markers in Vietnamese. Besides, they can be converted into Vietnamese by means of situation types of verbs. Even they can be translated by means of present adverbs expressing tense. Then, another conclusion can be also made is that sentences in present progressive tense can have even more choices of being translated via the use of present adverbs expressing tense, progressive, perfective aspectual markers and situation types of verbs. Lastly, it can be concluded that situation types of verbs can be employed to translate sentences of all the three English tenses namely the simple present tense, the present progressive tense and the simple past tense.

Although this study has succeeded in finding the answers to the questions, it has some limitations. Such limitations as the study focused on only three English tenses and aspects. One more restriction is the number of data was not many. Therefore, future studies are expected to investigate how to translate other English tenses and aspects into Vietnamese or even how to use English tenses and aspects to translate equivalent information from Vietnamese.

\section{Reference}

\section{Vietnamese}

Diệp Quang Ban (1992). Ngũ pháp tiếng Việt [Vietnamese grammar] (tập 2). Hà Nội: Nhà xuất bản Giáo dục.

Nguyễn Đức Dân (1996). Biểu hiện nhận diện thời gian trong tiếng Việt [Recognition of time in Vietnamese]. Ngôn ngứ, (3), 5-13.

Nguyễn Đức Dân (2009). Tri nhận thời gian trong tiếng Việt [Perception of time in Vietnamese]. Ngôn ngũu, (12), 1-14.

Đinh Văn Đức (2012). Thời và thể trong tiếng Việt: Nhìn từ hai phía ngữ pháp và tình thái [Tense and aspect in Vietnamese: Under grammar and modality views]. Tù điển hoc \& Bách khoa thu, (5), 11-19.

Cao Xuân Hạo (1998). Về ý nghĩa "thì" và "thể" trong tiếng Việt [On temporal and aspectual meanings in Vietnamese]. Ngôn ngũu, (5), 1-32.

Nguyễn Đình Hòa (1963). Các phạm trù ngữ pháp [Grammar categories]. Văn hóa nguyệt san, 12(78), 251-260.

Trần Trọng Kim, Bùi Kỷ, \& Phạm Duy Khiêm (1940). Việt Nam văn phạm [Vietnamese grammar]. Hà Nội: Tân Việt.

Đái Xuân Ninh (1984). Ngôn ngũ học, khuynh huoóng, lĩnh vục, khái niệm [Linguistics, trends, fields, notions] (tập 1). Hà Nội: Nhà xuất bản Khoa học Xã hội.

Nguyễn Anh Quế (1988). Hu tù trong tiếng Việt hiện đại [Function words in modern Vietnamese]. Hà Nội: Nhà xuất bản Khoa học Xã hội.

Nguyễn Kim Thản (1977). Nghiên cứu về ngũ pháp tiếng Việt [On Vietnamese grammar]. Hà Nội: Nhà xuất bản Giáo dục.

Nguyễn Minh Thuyết, \& Nguyễn Văn Hiệp (1998). Thành phần câu tiếng Việt [Vietnamese sentence structures]. Hà Nội: Nhà xuất bản Đại học Quốc gia Hà Nội.

Bùi Đức Tịnh (1952). Văn phạm Việt Nam [Vietnamese grammar]. Sài Gòn: Phạm Văn Tươi.

Nguyễn Hoàng Trung (2006). Hệ thống thể trong tiếng Việt (so sánh Việt - Pháp - Anh) [Aspects in Vietnamese (in comparison with French and English)]. Luận án Tiến sĩ, Đại học Quốc gia Thành phố Hồ Chí Minh.

Hoàng Tuệ (1962). Giáo trình Việt ngũ [Vietnamese course-book] (tập 1). Hà Nội: Nhà xuất bản Giáo dục.

\section{English}

Alexander, L. G. (1998). Longman English grammar practice for intermediate students. New York: Longman.

Baker, M. (1992). In other words: A coursebook on translation. London: Routledge. 
Bell, R. T. (1993). Translation and translating: Theory and practice. London and New York: Longman.

Catford, J. C. (1965). A Linguistic theory of translation: An essay on applied linguistics. London: Oxford University Press.

Comrie, B. (1976). Aspect: An introduction to the study of verbal aspect and related problems. Cambridge: Cambridge University Press.

Comrie, B. (1985). Tense. New York: Cambridge University Press.

Emeneau, M. (1951). Studies in Vietnamese (Annamese) grammar (Vol. 8). Berkeley and Los Angeles: University of California Press.

Finch, G. (2005). Key concepts in language and linguistics (2nd ed.). London: Palgrave Macmillan.

Geeraerts, D, \& Cuyckens, H. (2007). The Oxford handbook of cognitive linguistics. London: Oxford University Press.

Jakobson, R. (1959). On linguistic aspects of translation. In R. A. Brower (Ed.), On translation (pp. 232-239). London: Oxford University Press.

Jarvie, G. (1993). Grammar Guide: Grammar made easy. London: Bloomsbury Publishing Plc.

Jespersen, O. (1931). A modern English grammar on historical principles (Vol. 3). Heidlberg: C. Writers.

Kenny, D. (1998). Equivalence. In M. Baker (Ed.), Routledge encyclopedia of translation studies (pp. 77-79). London and New York: Routledge.
Munday, J. (2001). Introducing translation studies: Theories and applications. London and New York: Routledge.

Newmark, P. (1988). Approaches to translation. Oxford: Pergamon Press.

Nguyen, D. H. (1996). Vietnamese verbs. Mon-Khmer Studies, 25, 141-159.

Nida, E. (1964). Toward a science of translation. Leiden: E. J. Brill.

Niels, D. (1990). Tense and mood in English: A comparison with Danish. Berlin \& New York: Mouton de Gruyter.

Quirk, R., \& Greenbaum, S. (1973). A university of grammar of English. London: Longman.

Reichenbach, H. (1947). Elements of symbolic logic. New York: Free Press.

Richards, J. C., \& Schmidt, R. W. (2002). Longman dictionary of language teaching and applied linguistics. New York: Longman.

Salaberry, R., \& Shirai, Y. (2002). Tense-aspect morphology in L2 acquisition. Amsterdam and Philadelphia: John Benjamins.

Smith, C. (1997). The parameter of aspect (2nd ed.). Dordrecht; Boston: Kluwer.

Vendler, Z. (1967). Linguistics in philosophy. Ithaca, NY: Cornell University Press.

Venuti, L. (2000). The translation. London and New York: Routledge.

\section{VIÊC DICH THİ VÀ THỂ TỬ TIẾNG ANH SANG TIẾNG VIẸT}

\section{Nguyễn Đình Sinh}

\section{Truờng Đại học Su phạm Kỹ thuật Hưng Yên}

Tóm tắt: Nhầm lẫn hoặc tối nghĩa trong việc dịch thì và thể từ tiếng Anh sang tiếng Việt vẫn còn khá phổ biến ở nhiều bản dịch, nguyên nhân chủ yếu là do sự khác biệt trong quan niệm về khái niệm thì và thể của các nhà nghiên cứu và học giả của hai ngôn ngữ. Trong khi thì và thể tồn tại trong các mệnh đề hoặc câu tiếng Anh như một điều hiển nhiên thì trong tiếng Việt lại là chủ đề gây tranh cãi trong giới các nhà ngôn ngữ và nhà giáo dục. Nghiên cứu này nhằm tìm ra một số phương tiện ngôn ngữ được ba dịch giả nổi tiếng Việt Nam là Mặc Đỗ, Hoàng Cường và Trịnh Lữ sử dụng để dịch thì và thể trong câu thức trần thuật từ tiếng Anh sang tiếng Việt. Kết quả nghiên cứu cho thấy mặc dù thì và thể không luôn được công nhận trong tiếng Việt, chúng vẫn có thể dịch được từ tiếng Anh qua cách sử dụng trạng ngữ chỉ thời gian, chỉ dấu thể hoặc động từ cảnh huống trong tiếng Việt.

Tì khóa: thể, chỉ dấu thể, thức trần thuật, động từ cảnh huống, trạng ngữ chỉ thời gian, thì, dịch thuật. 